\title{
PERBEDAAN KEMAMPUAN PEMECAHAN MASALAH DENGAN PENDEKATAN INVESTIGASI DAN PENDEKATAN KONVENSIONAL PADA POKOK BAHASAN TEOREMA PHYTAGORAS DI KELAS VIII SMP NEGERI 9 PEMATANGSIANTAR
}

\author{
Theresia Monika Siahaan \\ Program Studi Pendidikan Matematika FKIP UHN Pematangsiantar \\ theresia_monika86@yahoo.com
}

\begin{abstract}
This study aims to determine whether there are differences in mathematical problem solving abilities of students who are taught through an investigative approach and with conventional approaches in class VIII SMP 9 of Pematangsiantar. This type of research is experimental research. The population in this study were all eighth grade students of SMP 9 of Pematangsiantar as many as 8 classes. The problem solving abilities of students taught with an investigative approach to the average pretest of 57.73 and post-test of 85.42, the level of change in problem solving abilities was 27.69. Higher than the problem solving abilities of students who are taught with conventional learning the average pretest is 56.67 and posttest is 72.67. Hypothesis testing, from the calculation of student pretest data obtained at $d k=64$ and the real level $\alpha=0.05$ and $t_{\left(1-\frac{1}{2} \alpha\right)}=t_{0,975}$ obtained $t_{\text {table }}=1.669$ and $t_{\text {count }}=1.172$. Because $t_{\text {count }}<t_{\text {table }}=(1.172<1.669)$ it can be concluded that the initial ability of students is the same. While based on the calculation of student posttest data obtained at $d k=64$ and the real level $\alpha=0.05$ obtained ttable $=1.669$ and $t$ count $=4.212$. Because tcount $>t_{\text {table }}(4.212>1.669)$ then $\mathrm{Ho}$ is rejected and $\mathrm{Ha}$ is accepted. Then it was concluded that there were significant differences between problem solving abilities taught by an investigative approach and conventional approaches.
\end{abstract}

Keywords: Problem Solving Ability, Investigative Approach, Conventional Approach.

\begin{abstract}
Abstrak. Penelitian ini bertujuan untuk mengetahui apakah ada perbedaan kemampuan pemecahan masalah matematika siswa yang diajar melalui pendekatan investigasi dan dengan pendekatan konvensional di kelas VIII SMP Negeri 9 Pematangsiantar. Jenis penelitian ini adalah penelitian eksperimen. Populasi dalam penelitian ini adalah seluruh siswa kelas VIII SMP Negeri 9 Pematangsiantar sebanyak 8 kelas. Kemampuan pemecahan masalah siswa yang diajar dengan pendekatan investigasi rata-rata pretes 57,73 dan postes 85,42 maka tingkat perubahan kemampuan pemecahan masalah adalah 27,69. Lebih tinggi daripada kemampuan pemecahan masalah siswa yang diajar dengan pembelajaran konvensional rata-rata pretes 56,67 dan postes 72,67. Uji hipotesisis, dari perhitungan data pretes siswa diperoleh pada $\mathrm{dk}=64 \mathrm{dan}$ taraf nyata $\alpha=0,05$ dan $t_{\left(1-\frac{1}{2} \alpha\right)}=t_{0,975}$ diperoleh $t_{\text {tabel }}=1,669$ dan $t_{\text {hitung }}=1.172$. Karena $t_{\text {hitung }}$ $<\mathrm{t}_{\text {tabel }}=(1,172<1,669)$ maka dapat disimpulkan bahwa kemampuan awal siswa sama. Sedangkan berdasarkan perhitungan data postes siswa diperoleh pada $\mathrm{dk}=64 \mathrm{dan}$ taraf nyata $\alpha=0,05$ diperoleh $t_{\text {tabel }}=1,669$ dan $t_{\text {hitung }}=4,212$. Karena $t_{\text {hitung }}>t_{\text {tabel }}(4,212>1,669)$ maka Ho ditolak dan Ha diterima. Maka disimpulkan ada perbedaan yang berarti antara kemampuan pemecahan masalah yang diajar dengan pendekatan investigasi dengan pendekatan konvensional.
\end{abstract}

Kata Kunci: Kemampuan Pemecahan Masalah, Pendekatan Investigasi, Pendekatan Konvesnional.

\section{PENDAHULUAN}

Pendidikan merupakan salah satu aspek yang memegang peranan penting dalam kehidupan. Pendidikan pada hakekatnya merupakan usaha manusia untuk memanusiakan manusia itu sendiri, yaitu membudayakan manusia. Pendidikan bertujuan untuk meningkatkan sumber daya manusia. Tinggi rendahnya kualitas pendidikan baik pendidikan formal maupun nonformal dipengaruhi oleh banyak faktor. Faktor yang 
mempengaruhi pendidikan formal yang berada di sekolah bisa berasal dari siswanya, pengajarannya, sarana-prasarananya, dan bisa juga karena faktor lingkungannya.

Kebutuhan untuk dapat memahami maupun menggunakan matematika dalam kehidupan sehari-hari semakin meningkat dan diperkirakan akan terus berkembang di masa yang akan datang. Hal ini disebabkan matematika memampukan orang berfikir, menganalisa dan memecahkan masalah. Matematika merupakan ilmu universal yang mendasari perkembangan teknologi modern, mempunyai peran penting dan mengembangkan daya pikir manusia. Perkembangan pesat dibidang teknologi informasi dan komunikasi dewasa ini dilandasi oleh perkembangan matematika. Damayanti (2012) menjelaskan bahwamatematika berfungsi mengembangkan kemampuan menghitung, mengukur, menurunkan dan menggunakan rumus matematika yang diperlukan dalam kehidupan sehari-hari melalui materi aljabar, geometri, logika matematika, peluang dan statistika. Matematika juga berfungsi mengembangkan kemampuan mengkomunikasikan gagasan melalui model matematika yang dapat berupa kalimat dan persamaan matematika, diagram, grafik dan tabel.

Matematika merupakan salah satu ilmu dasar yang harus dikuasai oleh siswa, karena matematika tidak bisa dilepaskan dari mata pelajaran lain. Terlepas dari itu, matematika banyak digunakan dalam kehidupan sehari-hari. Bahkan dalam perkembangan sains dan teknologi, matematika mempunyai peranan penting. Hal ini tidak di sadari oleh para siswa karena kurangnya informasi tentang fungsi dan peranan matematika itu sendiri. Sebagian siswa hanya tahu belajar matematika dengan menghapal rumus lalu menyelesaikan soal dengan menggunakan rumus yang sudah dihapal melalui operasi hitungan dengan bilangan (angka), huruf dan simbol tetapi tidak bermakna sehingga tidak melekat dibenak siswa.

Dengan melihat pentingnya matematika maka pelajaran matematika perlu diberikan kepada peserta didik mulai dari pendidikan dasar. Matematika dipelajari untuk membekali peserta didik dengan kemampuan berpikir logis, analisis, sistematik, kritis dan kreatif serta kemampuan bekerja sama. Kompetensi tersebut diperlukan agar peserta didik dapat memiliki kemampuan memperoleh, mengelola dan memanfaatkan informasi untuk bertahan hidup pada keadaan yang selalu berubah tidak pasti dan kompetitif.

Permasalahan dalam proses belajar mengajar dewasa ini adalah kecenderungan umum bahwa para siswa hanya terbiasa menggunakan sebagian kecil saja dari potensi atau kemampuan berpikirnya. Seiring juga dalam penyampaian materi, jika guru kurang tepat menyampaikannya dapat membuat anak didik merasa bosan dan jenuh. Dalam pembelajaran matematika penyampaian guru cenderung bersifat monoton, hampir tanpa variasi kreatif, kalau saja siswa ditanya ada saja alasan yang mereka kemukakan seperti matematika sulit, tidak mampu menjawab, sukar, takut disuruh guru ke depan dan sebagainya, sehingga menimbulkan adanya gejala matematika phobia (ketakutan anak terhadap matematika) yang melanda sebagian besar siswa. Guru dalam pembelajarannya di kelas tidak mengaitkan dengan skema yang telah dimiliki oleh siswa dan siswa kurang diberikan kesempatan untuk menemukan kembali dan mengkonstruksi sendiri ide-ide mereka dalam pembelajaran.

Belajar merupakan tindakan dan perilaku siswa yang kompleks. Sebagai tindakan, maka belajar hanya dialami oleh siswa sendiri. Siswa adalah penentu terjadi atau tidak terjadinya proses belajar. Proses belajar terjadi berkat siswa memperoleh sesuatu dilingkungan sekitar. Lingkungan yang dipelajari oleh siswa berupa keadaan alam, bendabenda, hewan, tumbuh-tumbuhan, manusia atau hal yang dijadikan bahan belajar.

Dalam upaya meningkatkan kemampuan pemecahan masalah matematika siswa, hendaknya guru berusaha melatih dan membiasakan siswa melakukan kegiatan pembelajaran seperti memberikan latihan-latihan soal dan memecahkan masalah-masalah matematika yang ada. Dengan adanya pemecahan masalah matematika, maka siswa 
diharapkan lebih mudah memahami konsep matematika yang ada. Hudojo (2001) juga menyatakan bahwa pemecahan masalah mempunyai fungsi yang penting dalam kegiatan belajar mengajar matematika. Melalui pemecahan masalah matematika siswa-siswa dapat berlatih dan mengintegrasikan konsep-konsep, teorema-teorema dan keterampilan yang telah dipelajari.

Pemecahan masalah merupakan bagian dari kurikulum matematika yang sangat penting karena dalam proses pembelajaran maupun penyelesaiannya, siswa dimungkinkan memperoleh pengalaman menggunakan pengetahuan serta keterampilan yang sudah dimiliki untuk diterapkan pada pemecahan masalah yang sifatnya tidak rutin.

Pemecahan masalah matematika merupakan salah satu kegiatan matematika yang dianggap penting baik oleh para guru maupun siswa di semua tingkatan mulai dari Sekolah Dasar sampai Perguruan Tinggi. Untuk mengembangkan kemampuan siswa dalam pemecahan masalah dibutuhkan seorang guru. Model petunjuk guru untuk membantu siswa menyelesaikan masalah menurut Hudojo (1979) adalah 1) Membuat siswa-siswa mengerti masalahnya; 2) Membantu siswa-siswa menghimpun pengalaman-pengalaman belajar yang relevan yang sekiranya memudahkan perencanaan penyelesaian; dan 3) Membawa siswa-siswa ke situasi yang mendorong untuk menyelesaikan suatu masalah.

Klurik (1980) memberikan petunjuk tentang prosedur yang efektif bagi siswa untuk memahami masalah yang dihadapinya. Petunjuk itu adalah: 1) Bacalah pertanyaan dalam masalah secara lengkap untuk dapat menghimpun ide-ide umum yang dapat mewakili keadaan tersebut; 2) Pahami pernyataan dan hubungan-hubungan yang terdapat didalamnya; 3) Susun dan organisasikanlah langkah-langkah utama untuk memberi kemungkinan pada pemecahan masalah; dan 4) Bacalah masalah lebih dari satu kali untuk memastikan prosedur yang akan digunakan.

Selain kesulitan belajar yang dihadapi oleh siswa itu sendiri, rendahnya kemampuan pemecahan masalah matematika siswa juga disebabkan oleh metode pembelajaran yang masih berpusat pada guru. Disamping itu, sebagaimana yang diungkapkan oleh salah seorang guru matematika (R. Manik) di SMP Negeri 9 Pematang Siantar. Rendahnya kemampuan pemecahan masalah oleh siswa disebabkan oleh beberapa faktor yaitu: 1) Siswa tidak peduli dengan masalah yang ada, sehingga tidak ada kemauan untuk mengerjakan masalah dan berlalu begitu saja; 2) Siswa tidak memiliki rasa percaya diri dalam memecahkan masalah dan selalu mengharapkan dari orang lain yang mengakibatkan pekerjaannya selesai tanpa dipikirkan dengan baik; dan 3) Siswa tidak mau mencari tambahan referensi buku yang mendukung setiap tugas yang diberikan oleh guru.

Agar kemampuan pemecahan masalah dalam matematika dapat berhasil maka dibutuhkan peran aktif siswa. Oleh karena itu perlu diusahakan suatu pendekatan pembelajaran yang mengaktifkan siswa dalam proses belajar mengajar. Cara belajar aktif merupakan cara belajar yang dituntut dari siswa agar mereka dapat meningkatkan prestasi belajarnya. Pendekatan investigasi matematika berkaitan dengan belajar berfikir seperti pola berfikir ilmiah. Fatihazzuri (17 Januari 2010) menyatakan bahwa kegiatan pembelajaran memberikan kemungkinan kepada siswa untuk mengembangkan pemahaman siswa melalui berbagai kegiatan. Kegiatan belajar dimulai dengan masalah-masalah yang diberikan oleh guru sedangkan kegiatan belajar selanjutnya cenderung terbuka artinya tidak terstruktur secara ketat oleh guru yang dalam pelaksanaanya mengacu pada teori investigasi.

Istilah investigasi mulai diperkenalkan oleh Cockcroft (1987) yang menyatakan bahwa pembelajaran matematika harus melibatkan aktivitas berikut yakni eksposisi (pemaparan), diskusi diantara siswa sendiri ataupun antara siswa dan guru, kerja praktek, pemantapan dan latihan pengerjaan sosial dan investigasi. Menurut Joyce, Weil \& Calhoun (2000), model ini sangat mudah disesuaikan dan komprehensip yang menggabungkan 
tujuan-tujuan akademik investigasi, integrasi sosial dan proses pembelajaran sosial dan dapat digunakan dalam semua bidang studi dan semua tingkatan. Height (Krismanto, 2004), investigasi berkaitan dengan kegiatan mengobservasi secara rinci dan menilai secara sistematis. Jadi investigasi adalah proses penyelidikan yang dilakukan oleh seseorang dan selanjutnya orang tersebut mengkomunikasikan hasil perolehannya dapat membandingkannya dengan perolehan orang lain karena dalam suatu investigasi dapat diperoleh satu hasil atau lebih.

Proses pengerjaan dalam investigasi tidak hanya dituntut untuk mendapat pemecahan yang tertentu, tetapi dituntut pula untuk mengembangkan kemungkinan permasalahan dan pemecahan lain. Penyesuain metode pengajaran dengan materi matematika itu memang sulit, sebab matematika itu sulit ditransfer pada siswa. Hal ini dapat dimaklumi sebab kadang guru tidak dapat memberi langkah awal yang segera dimengerti oleh siswa. Hubungan yang terdapat pada pemecahan masalah didukung oleh pendekatan investigasi. Pemecahan masalah dapat digunakan dengan pendekatan investigasi. Dengan menggunakan pendekatan investigasi akan membantu siswa lebih mudah menyelesaikan masalah yaitu 1) Memahami masalah, pada investigasi mencek persoalan; 2) Membuat rencana penyelesaian, pada investigasi mengevaluasi pekerjaan; 3) Melaksanakan rencana penyelesaian masalah, pada investigasi mencatat dan menginterpretasikan hasil yang diperoleh; dan 4) Memeriksa kembali, pada investigasi mentransfer keterampilannya untuk diterapkan pada persoalan yang lebih kompleks.

\section{METODE}

Jenis penelitian ini adalah penelitian eksperimen. Desain penelitian ini menggunakan randomimized control-group pretest-postes. Sampel yang di ambil dalam penelitian ini dikelompokkan menjadi dua kelompok yaitu kelompok pertama sebagai kelas pertama (VIII-1) dan kelompok kedua sebagai kelas kontrol (VIII-2). Pada kelas eksperimen diberi perlakuan pembelajaran dengan menggunakan pendekatan investigasi, sedangkan kelas kontrol diberikan pendekatan konvensional. Kedua kelas sampel tersebut terlebih dahulu diberikan pretes untuk mengetahui kemampuan atau pemahaman siswa mengenai pokok bahasan yang akan diajarkan sebelum dilakukan pembelajaran. Untuk lebih jelasnya dapat dilihat pada kelompok dan perlakuan siswa sebagai berikut:

Tabel 1. Desain Penelitian

\begin{tabular}{cccc}
\hline Kelas Sampel & Pre Test & Perlakuan & Post Test \\
\hline Eksperimen & $\mathrm{T}_{1}$ & $\mathrm{X}_{1}$ & $\mathrm{~T}_{2}$ \\
\hline Kontrol & $\mathrm{T}_{1}$ & $\mathrm{X}_{2}$ & $\mathrm{~T}_{2}$ \\
\hline
\end{tabular}

Keterangan:

$\mathrm{X}_{1}$ : Perlakuan dengan Pendekatan Investigasi

$\mathrm{X}_{2}$ : Pendekatan Pembelajaran Konvensional

$\mathrm{T}_{1}$ : Pemberian Pre Test

$\mathrm{T}_{2}$ : Pemberian Pos Test

Teknik analisis data yang digunakan dalam pengujian hipotesis adalah dengan menggunakan uji-t. Adapun hipotesis yang akan diuji dalam penelitian ini adalah sebagai berikut:

$H_{0}: \mu_{1}=\mu_{2}$ tidak ada perbedaan yang signifikan antara kemampuan pemecahan masalah matematika siswa yang diajarkan melalui pendekatan investigasi dan pendekatan konvensional di kelas VIII SMP Negeri 9 Pematang Siantar. 
Perbedaan Kemampuan Pemecahan Masalah dengan Pendekatan Investigasi...

$H_{0}: \mu_{1} \neq \mu_{2}$ ada perbedaan yang signifikan antara kemampuan pemecahan masalah siswa yang diajarkan melalui pendekatan investigasi dan pendekatan konvensional di kelas VIII SMP Negeri 9 Pematang Siantar

\section{HASIL DAN PEMBAHASAN}

Dari hasil pengolahan nilai postes di kelas kontrol maka diperoleh perbedaan ratarata antara kedua kelas tersebut. Rata-rata nilai siswa di kelas kontrol adalah 72,67 sedangkan rata-rata nilai siswa di kelas eksperimen adalah 85,42. Distribusi frekuensi nilai kemampuan pemecahan masalah matematika siswa pada kelas kontrol dapat dilihat pada tabel di bawah ini.

Tabel 2. Distribusi Frekuensi Kelas Kontrol

\begin{tabular}{ccc}
\hline Interval & Batas Kelas & $\mathbf{f}_{\mathbf{i}}$ \\
\hline $30-40$ & $29,5-40,5$ & 1 \\
\hline $41-51$ & $40,5-51,5$ & 1 \\
\hline $52-62$ & $52,5-62,5$ & 4 \\
\hline $63-73$ & $62,5-73,5$ & 12 \\
\hline $74-84$ & $73,5-84,5$ & 7 \\
\hline $85-95$ & $84,5-95,5$ & 8 \\
\hline & & 33 \\
\hline
\end{tabular}

Distribusi frekuensi nilai kemampuan pemecahan masalah matematika siswa pada kelas kontrol dapat dilihat pada tabel berikut.

Tabel 3. Distribusi Frekuensi Kelas Eksperimen

\begin{tabular}{ccc}
\hline Interval & Batas Kelas & $\mathbf{f}_{\mathbf{i}}$ \\
\hline $61-67$ & $60,5-67,5$ & 2 \\
\hline $68-74$ & $67,5-74,5$ & 5 \\
\hline $75-81$ & $74,5-81,5$ & 4 \\
\hline $82-88$ & $81,5-88,5$ & 5 \\
\hline $89-95$ & $88,5-95,5$ & 12 \\
\hline $96-102$ & $95,5-102,5$ & 5 \\
\hline & & 33 \\
\hline
\end{tabular}

Telah diketahui bahwa kedua kelompok data kemampuan pemecahan masalah matematika siswa adalah berdistribusi normal dan mempunyai varians yang homogen, dengan demikian pengujian hipotesis dilakukan melalui uji satu pihak yaitu uji-t. Dari perhitungan diperoleh $\mathrm{T}_{\text {hitung }}=4,212$. Pada dk $=64$ dan taraf nyata $\alpha=0,05$ diperoleh $T_{\text {tabel }}$ $=1,669$, sehingga terlihat jelas bahwa $T_{\text {hitung }}>F_{\text {tabel }}(4,212>1,669)$.

Berdasarkan pengujian hipotesis ternyata Ho ditolak dan Ha diterima. Dengan demikian ada perbedaan antara kemampuan pemecahan masalah matematika siswa yang diajar melalui pendekatan investigasi dengan kemampuan pemecahan masalah siswa yang diajar melalui pendekatan konvensional pada pokok bahasan teorema phytagoras pada siswa kelas VIII SMP Negeri 9 Pematangsiantar.

Berdasarkan data hasil pemecahan masalah ditemukan bahwa kemampuan pemecahan masalah siswa dengan pendekatan investigasi lebih tinggi daripada pendekatan konvensional pada pokok bahasan teorema phytagoras. Rata-rata pre-tes untuk kelas kontrol sebasar sebesar 56,67 dan standar deviasi 13,93. Sedangkan untuk kelas eksperimen rata-rata pre-tes yang diperoleh sebesar 57,73 dan standar deviasi 13,08. Nilai rata-rata 
post-tes untuk kelas konvensional sebesar 72,67 dan standar deviasi 13,76. Sedangkan untuk kelas eksperimen rata-rata post-tes yang diperoleh sebesar 85,42 dan standar deviasi 10,64 .

Pembelajaran dengan menggunakan pendekatan investigasi membuat siswa lebih senang belajar karena siswa didorong belajar dengan cara mencek persoalan yang ada,mengevaluasi pekerjaan, menginterpretasikan hasil dan mentransfer keterampilannya untuk diterapkan. Sedangkan pada kelas konvensional dapat dilihat bahwa antusias siswa dalam belajar cukup rendah, karena proses pembelajaran terkesan monoton, dimana siswa hanya mendengarkan penjelasan guru, dan guru menerangkan, tanpa ada melibatkan terjadinya interaksi sehingga suasana belajar terasa kaku.

Berdasarkan temuan-temuan penelitian maka dapat dikatakan bahwa kemampuan pemecahan masalah dengan pendekatan investigasi lebih baik daripada yang diajar pendekatan konvensional. Hal ini membuktikan bahwa penggunaan pendekatan investigasi dalam proses pembelajaran diperlukan pada pembelajaran matematika pada pokok bahasan teorema phytagoras..

Untuk memperkuat hasil penelitian ini maka dibandingkan dengan penelitian yang relevan yang dilakukan oleh Dosnita nainggolan menyatakan bahwa kemampuan pemecahan masalah yang memperoleh pendekatan investigasi lebih tinggi dibandingkan pendekatan konvensional. Hal ini menunjukkan ada perbedaan yang signifikan pemecahan masalah antara yang memperoleh pendekatan investigasi dengan pendekatan konvensional. Adapun dalam pembelajaran berlangsung terdapat beberapa kelemahan peneliti antara lain:

1. Suasana dalam kelas tidak terkontrol (ribut) karena siswa kurang terbiasa dengan cara pembelajaran pendekatan investigasi.

2. Kesulitan untuk membuat siswa lebih berani mengungkapkan pendapatnya.

3. Memerlukan banyak waktu untuk menerapkan pendekatan investigasi sehingga memungkinkan banyak bahan pelajaran yang akan tertinggal.

\section{KESIMPULAN}

Berdasarkan hasil analisis data serta pengujian hipotesis, peneliti mengemukakan kesimpulan dan saran sesuai dengan penelitian ini.

1. Kemampuan pemecahan masalah yang diajarkan dengan pendekatan investigasi lebih baik daripada kemampuan pemecahan masalah yang diajarkan dengan pendekatan konvensional pada pokok bahasan teorema phytagoras di kelas VIII SMP Negeri 9 Pematangsiantar.

2. Pada pokok bahasan teorema phytagoras, pendekatan investigasi telah dapat menuntaskan pemecahan masalah siswa sedangkan pendekatan konvensional belum dapat menuntaskan pemecahan masalah siswa.

\section{DAFTAR PUSTAKA}

B. Weil, Joyce and Calhoun. 2000. Models of Teaching. Newyork: A Person Education Company.

Cockroft. 1987. Mathemathics Counts. London: Her Majesty's Stationery Office.

Damayanti, I. O. 2012. Penggunaan Balok Sempoa dalam Meningkatkan Kemampuan

Operasi Hitung Perkalian pada Siswa Tunarungu. Jassi Anakku, 11(2): 125-133.

Hudojo, H. 1979. Pengembangan Kurikulum matematika dan Pelaksanaannya di Depan Kelas. Surabaya: Usaha Nasional.

Hudojo, H. 1982. Mengajar Belajar Matematika. Jakarta: Depdikbud.

Krismanto, A. 2003. Beberapa Teknik, Model,dan Strategi dalam. Pembelajaran Matematika. Yogyakarta: Pusat Pengembangan Penataran Guru Matematika. 

Perbedaan Kemampuan Pemecahan Masalah dengan Pendekatan Investigasi...

Krulik, S. 1980. Problem Solving in School Mathematics. Virginia: National Council of Mathematics.

Sanjaya, W. 2008. Strategi Pembelajaran. Jakarta: Prenada Media Group.

Setiawan. 2006. Model pembelajaran Matematika dengan Pendekatan Investigasi, Departemen Pendidikan Nasional Pusat Pengembangan dan Penataran Guru Matematika. Yogyakarta.

Soejono. 1980. Pengajaran Matematika untuk Sekolah Menengah. Jakarta: Dirjen Dikti. 